\title{
Muscarinic Modulation of Spike Backpropagation in the Apical Dendrites of Hippocampal CA1 Pyramidal Neurons
}

\author{
Hiroshi Tsubokawa and William N. Ross \\ Department of Physiology, New York Medical College, Valhalla, New York 10595
}

In pyramidal neurons from the CA1 region of the rat hippocampus, $\mathrm{Na}^{+}$-dependent action potentials backpropagate over the dendrites in an activity-dependent manner. Consequently, later spikes in a train have smaller amplitudes when recorded in the apical arbors. We studied the effect of the cholinergic agonist carbachol (CCh) on this pattern of activity when spikes were evoked synaptically or antidromically in the transverse slice preparation. Concentrations as low as $1 \mu \mathrm{M}$ were effective in reversing the modulation, making the amplitude of all spikes in a train equal and independent of the frequency of spike firing. CCh did not change the propagation of the first spike in a train. These effects of CCh were blocked by $1 \mu \mathrm{M}$ atropine, showing that only muscarinic receptors were involved. The effects of CCh on the pattern of spike propagation were observed in the proximal and middle dendrites, but recordings in the distal dendrites ( $>300 \mu \mathrm{m}$ from the soma) showed that CCh did not boost the amplitude in this region. Intracellular BAPTA (10 mm) or EGTA (10 mm) had no effect on activity-dependent backpropagation but blocked the effect of CCh. Backpropagating spikes caused increases in $\left[\mathrm{Ca}^{2+}\right]_{\mathrm{i}}$ at all dendritic locations. In the middle and distal dendrites these increases normally peaked at the time of the first few large action potentials. In association with the enhancement of spike backpropagation, $\mathrm{CCh}$ increased the amplitude and duration of the train-evoked $\left[\mathrm{Ca}^{2+}\right]_{\mathrm{i}}$ changes. These effects of $\mathrm{CCh}$ on dendritic spike potentials and associated $\left[\mathrm{Ca}^{2+}\right]_{i}$ changes may be important in modulating synaptic integration and plasticity in these neurons.

Key words: pyramidal neuron; dendrite; carbachol; muscarine; hippocampus; backpropagation; calcium concentration; action potential
Cholinergic agonists cause an increase in firing rate and a reduction in spike accommodation in pyramidal neurons from the CA1 region of the hippocampus (Nicoll, 1985). These changes are mediated by a combination of effects, including a depolarization associated with an increase in membrane resistance (Dodd et al., 1981; Cole and Nicoll, 1984), a blockade of the slow afterhyperpolarization that follows action potentials (Bernardo and Prince, 1982), a blockade of the M-current (Halliwell and Adams, 1982), and the activation of a nonselective cation conductance (Benson et al., 1988). All of these effects seem to be mediated via muscarinic receptors (Nicoll, 1985).

The changes in spike firing rates clearly are important, because these action potentials represent the immediate message that these cells transmit to other cells. However, neurons can be modulated in other ways with different physiological consequences. Of particular interest are effects on dendritic properties, because they are the primary locus of synaptic integration and plasticity. The apical dendrites of CA1 pyramidal neurons have voltage-dependent channels (Magee and Johnston, 1995a,b) and conduct $\mathrm{Na}^{+}-$and $\mathrm{Ca}^{2+}$. dependent action potentials (Wong et al., 1979). These spikes usually are initiated near the soma (Turner et al., 1991; Spruston et al., 1995a) and backpropagate over the dendrites, causing transient increases in $\left[\mathrm{Ca}^{2+}\right]_{\mathrm{i}}$ (Jaffe et al., 1992; Regehr and Tank, 1992; Callaway and Ross, 1995; Spruston et al., 1995a) that are important in regulating some forms of synaptic plasticity (Gustafsson et al., 1987; Kullman et al., 1992; Magee and Johnston, 1997; Markram et

\footnotetext{
Received Feb. 24, 1997; revised May 5, 1997; accepted May 20, 1997.

This work was supported in part by grants from the Human Frontier Science Program and the National Institute of Neurological Disorders and Stroke (NS16295) and a fellowship from the Naito Foundation. We thank Ege Kavalali, Jurgen Klingauf, John Lisman, and Dick Tsien for comments on this manuscript.

Correspondence should be addressed to Dr. William N. Ross at the above address.

Copyright (C) 1997 Society for Neuroscience $0270-6474 / 97 / 175782-10 \$ 05.00 / 0$
}

al., 1997). Consequently, factors that influence spike propagation in the dendrites may be important in controlling the spatial extent of synapse modification.

Both imaging experiments and intradendritic recording (Jaffe et al., 1992; Andreasen and Lambert, 1995; Callaway and Ross, 1995; Spruston et al., 1995a) have shown that backpropagation is activity-dependent, with later spikes in a train failing to reach the distal arbors. The mechanism responsible for this frequencydependent propagation is unknown, nor is it known whether this pattern is modified during normal behavior. In these experiments we examined a number of factors that could affect dendritic spike propagation. The clearest result was from the cholinergic agonist carbachol $(\mathrm{CCh})$, which made all spikes in a train propagate equally into the dendrites up to the molecular layer, increasing the magnitude and spatial extent of the $\left[\mathrm{Ca}^{2+}\right]_{\mathrm{i}}$ change resulting from the train.

Some of these results have been reported previously in abstract form (Tsubokawa and Ross, 1996b).

\section{MATERIALS AND METHODS}

Transverse hippocampal slices (250-300 $\mu \mathrm{m}$ thick) were prepared from 3- to 5-week-old Sprague Dawley rats as previously described (Tsubokawa and Ross, 1996a), with the following modifications. The cutting solution was ice-cold and consisted of (in $\mathrm{mM}$ ): 120 choline-Cl, $3 \mathrm{KCl}, 8$ $\mathrm{MgCl}_{2}, 1.25 \mathrm{NaH}_{2} \mathrm{PO}_{4}, 26 \mathrm{NaHCO}_{3}$, and 10-20 glucose. Control slices cut using normal saline, sucrose instead of choline- $\mathrm{Cl}$, or saline with 0 $\mathrm{Ca}^{2+}$ and low $\mathrm{Na}^{+}$produced similar data. After they were cut, slices were incubated at $35^{\circ} \mathrm{C}$ for $\sim 1 / 2 \mathrm{hr}$ and then maintained at room temperature. The normal incubation solution was composed of (in mM): 124 $\mathrm{NaCl}, 2.5 \mathrm{KCl}, 2 \mathrm{CaCl}_{2}, 2 \mathrm{MgCl}_{2}, 1.25 \mathrm{NaH}_{2} \mathrm{PO}_{4}, 26 \mathrm{NaHCO}_{3}$, and 10 glucose, bubbled with a mixture of $95 \% \mathrm{O}_{2} / 5 \% \mathrm{CO}_{2}$, making the final $\mathrm{pH}$ 7.4. For most experiments $0.4 \mathrm{~mm}$ L-ascorbic acid and $1.5-3.0 \mathrm{~mm}$ myo-inositol were added to this solution to improve slice viability (Borst et al., 1995). Control experiments established that these additives had no effect on the cell properties described in this paper. For recording, slices 
were transferred to a submerged chamber superfused with the same solution at $30-32^{\circ} \mathrm{C}$.

Most experiments were made in a chamber set on the stage of an Olympus IMT-2F inverted microscope (Callaway et al., 1995; Tsubokawa and Ross, 1996a). Submerged slices were viewed from above with a dissecting microscope mounted coaxially with the inverted microscope objectives. Bipolar electrodes, constructed from Teflon-coated tungsten wires, were placed on the alveus for stimulating antidromic spikes and on the stratum radiatum (SR) for generating EPSPs. Stimulating pulses were $100-1000 \mu \mathrm{A}$ for $100-200 \mu \mathrm{sec}$. Intracellular recordings were made by using patch pipettes pulled from $1.5 \mathrm{~mm}$ outer diameter thick-walled glass tubing (No. 1511-M, Friderick and Dimmock, Millville, NJ). Tight seals $(>5 \mathrm{G} \Omega$ ) were made by the "blind" approach (Blanton et al., 1989). For most experiments the pipette solution contained (in $\mathrm{mM}$ ): 130 K-gluconate, $10 \mathrm{Na}$-gluconate, $4 \mathrm{NaCl}, 2-4 \mathrm{Mg}$-ATP, $0.3 \mathrm{Na}-\mathrm{GTP}$, and 10 HEPES, pH-adjusted to 7.2 with $\mathrm{KOH}$. In some experiments K-ATP was substituted for Mg-ATP. Open resistance of the pipettes was 5-7 M $\Omega$ for somatic recordings and 6-10 $\mathrm{M} \Omega$ for dendritic recording. Capacitance was compensated almost fully. No correction was made for the junction potential between the bath and the pipette. Spike amplitudes were measured from resting potential ( $-61 \pm 4 \mathrm{mV}$ at all locations). All amplitudes presented in this paper are the average of at least five trials. The typical variation was $<2 \mathrm{mV}$.

Perforated patch recordings. Most recordings were made by the standard whole-cell technique that exchanges the intracellular solution. Because muscarinic responses involve intracellular messengers (Krnjevic, 1993), we made some measurements with the perforated patch technique that avoids dialysis (Horn and Marty, 1988; Spruston and Johnston, 1992). For these experiments the pipette contained $200 \mu \mathrm{g} / \mathrm{ml}$ nystatin, $0.4 \%$ DMSO, and (in mM): $120 \mathrm{~K}$-gluconate, $20 \mathrm{KCl}, 2 \mathrm{MgCl}_{2}$, and $10 \mathrm{HEPES}$, $\mathrm{pH}$ 7.2. With these nystatin-containing pipettes, tight seals were made with the same blind technique used for whole-cell recording. Usually, the access resistance was reduced gradually to $<50 \mathrm{M} \Omega$ within 15 min from the time of seal formation. In many experiments we confirmed that the low access resistance did not mean a whole-cell configuration by observing that the fluorescence of a small amount of added fura- 2 was confined to the pipette.

Calcium concentration measurements. Measurements of $\left[\mathrm{Ca}^{2+}\right]_{\mathrm{i}}$ changes were made in a chamber mounted on an upright Olympus BX50WI microscope. For these experiments $200 \mu \mathrm{M}$ bis-fura- 2 or 200 $\mu \mathrm{M}$ Calcium Green-1 (B-6910 and C-3010, Molecular Probes, Eugene, OR) was added to the standard pipette solution. Tight seals on dendrites were made under visual control, using a $40 \times$ water immersion lens and video-enhanced DIC optics (Stuart and Sakmann, 1994). After allowing the indicator to diff use into the cell ( $\geq 15 \mathrm{~min}$ after rupturing the seal), we recorded high-speed images ( $25 \mathrm{msec}$ frame interval) with a cooled CCD camera (Lasser-Ross et al., 1991). These images typically had a spatial resolution of $3 \mu \mathrm{m} /$ pixel. Images of the cell (as in Fig. 3) were taken at a resolution of $0.6 \mu \mathrm{m} /$ pixel. Changes in $\left[\mathrm{Ca}^{2+}\right]_{\mathrm{i}}$ are presented as the spatial average of $\Delta F / F$ (percent), in which $F$ is the fluorescence intensity at resting membrane potential (corrected for background autofluorescence) and $\Delta F$ is the time-dependent change in fluorescence (corrected for bleaching). Bis-fura-2 fluorescence was measured, using excitation of $382 \pm 10 \mathrm{~nm}$ and emission $>455 \mathrm{~nm}$. Calcium Green-1 fluorescence was measured, using excitation of $475 \pm 15 \mathrm{~nm}$ and emission between 515 and $550 \mathrm{~nm}$.

Identification of pyramidal neurons. Cells that were patched on dendrites using the blind technique were identified as pyramidal neurons primarily by their response to stimulation in the alveus in the presence of $50 \mu \mathrm{M}$ DL-2-amino-5-phosphonovaleric acid (DL-APV), $10 \mu \mathrm{M}$ 6-cyano-7nitroquinoxaline-2,3-dione (CNQX), and $10 \mu \mathrm{M}$ bicuculline methiodide (BMI) and by their characteristic firing pattern after trains of stimuli. Occasionally, this identification was confirmed by observing the cell shape determined by the fluorescence of fura- 2 included in the pipette.

Chemicals. All reagents were obtained from Sigma (St. Louis, MO) except atropine and CNQX, which were obtained from Research Biochemicals International (Natick, MA). Norepinephrine, APV, and BMI were purchased from both companies.

\section{RESULTS}

Extracellular stimulation in the stratum radiatum evoked a mixture of excitatory and inhibitory synaptic potentials in CA1 pyramidal neurons. If the potentials were large enough, action potentials were generated. When they were recorded in the dendrites,

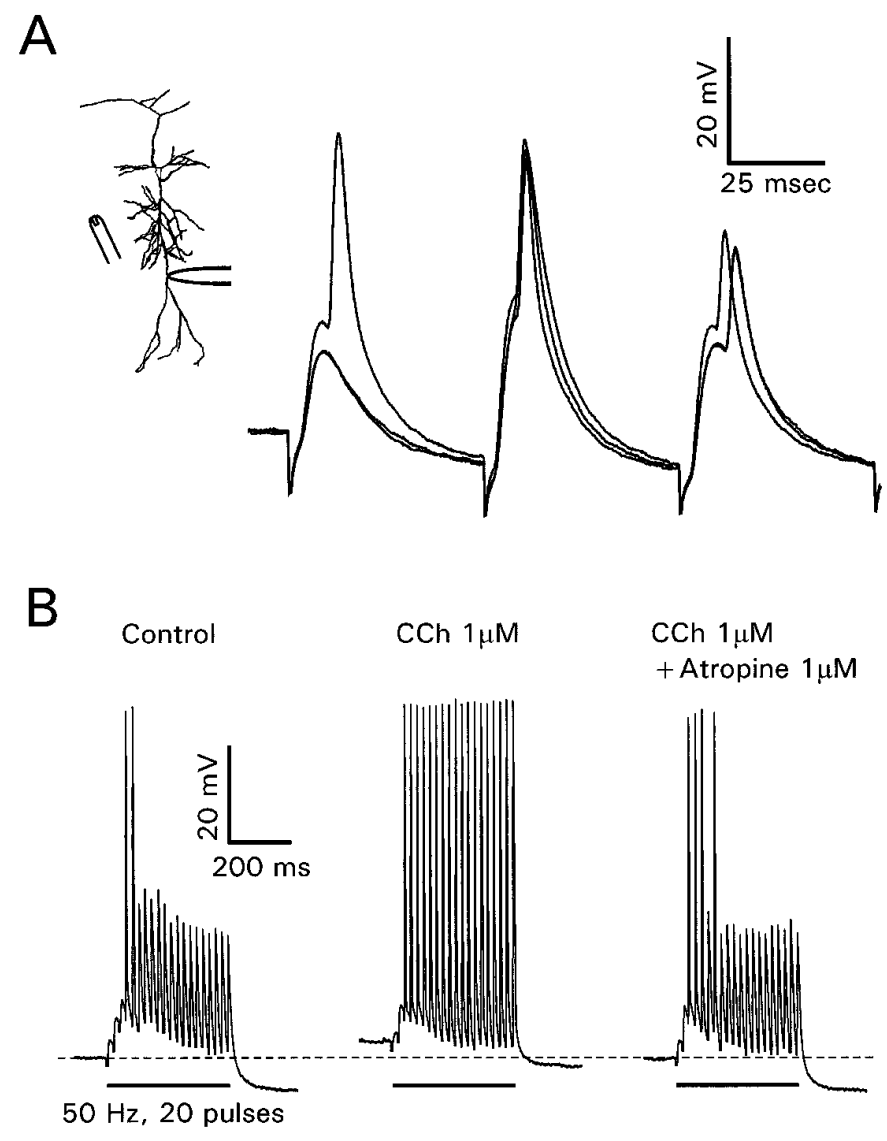

Figure 1. Carbachol enhances the propagation of synaptically activated action potentials in the dendrites. $A$, Recording of synaptically activated action potentials in the apical dendrites $300 \mu \mathrm{m}$ from the soma. Sketch illustrates positions of recording and stimulating electrodes. Several traces are superimposed. Note that (1) most action potentials were initiated on the falling phase of the synaptic potential, (2) the amplitudes of the evoked action potentials decreased during the train, and (3) the second spike was initiated earlier because of the facilitated synaptic potential. $B$, Different cell, recording $200 \mu \mathrm{m}$ from the soma, with $1.0 \mu \mathrm{M}$ picrotoxin added to the bath. In control conditions synaptic responses evoked a train of actions potentials, but only the first two had large amplitudes. Adding $1 \mu \mathrm{M}$ CCh made all spikes have equal amplitude. Further addition of $1 \mu \mathrm{M}$ atropine restored the control response.

these action potentials typically rose on the falling phase of the EPSP (Fig. 1 $A$ ), consistent with their generation in the axon hillock region of the cell (Turner et al., 1991; Spruston et al., 1995a; Colbert and Johnston, 1996a). During a train $(50 \mathrm{~Hz})$ of synaptic stimuli the amplitudes of the evoked spikes showed decrements, as seen after antidromic or intrasomatic stimulation (Callaway and Ross, 1995; Spruston et al., 1995a). When the stimulation intensity was near threshold for action potential generation, the buildup of the IPSP usually prevented the generation of spikes after the first few EPSPs. To evoke a consistent train of action potentials and to avoid the effects of inhibition on spike backpropagation (Tsubokawa and Ross, 1996a), we added $1 \mu \mathrm{M}$ picrotoxin to the bathing solution. This concentration was low enough not to cause burst responses. In this condition each EPSP (after the first few) evoked an action potential (Fig. 1B). However, only the first two spikes fully propagated to the recording site $200 \mu \mathrm{m}$ from the soma (see also Spruston et al., 1995a). When $1 \mu \mathrm{M} \mathrm{CCh}$ (a cholinergic agonist insensitive to acetylcholinesterase) was added to the bath, all of the action potentials propagated 
Control

$$
\mathrm{CCh} 1 \mu \mathrm{M}
$$
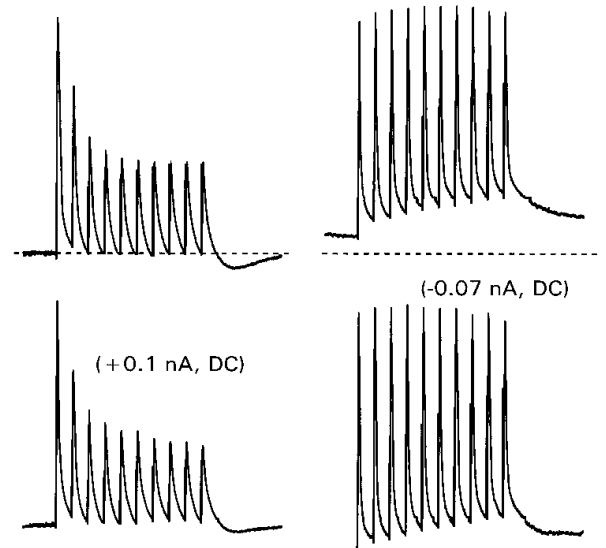

$(-0.07 n A, D C)$

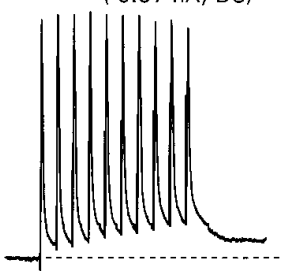

CCh $1 \mu \mathrm{M}$ + Atropine $1 \mu \mathrm{M}$
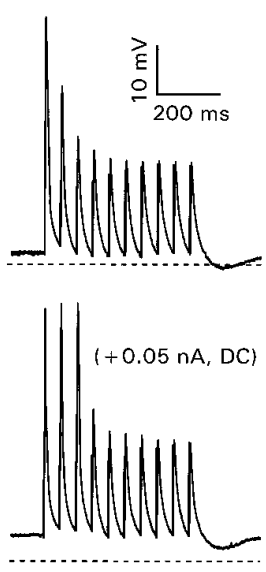

Figure 2. Carbachol enhances backpropagation of antidromically evoked spikes by a mechanism independent from membrane depolarization. This recording site is $250 \mu \mathrm{m}$ from the soma. In control conditions (top left) spikes evoked at $50 \mathrm{msec}$ intervals showed decrements in amplitude. Depolarizing the cell with $+0.1 \mathrm{nA}$ through the recording electrode did not change the pattern (bottom left). CCh $(1 \mu \mathrm{M})$ depolarized the cell $\approx 5$ $\mathrm{mV}$ and enhanced the amplitude of later spikes (top middle). Restoring the resting potential with $-0.07 \mathrm{nA}$ did not change the spike pattern. Atropine $(1 \mu \mathrm{M})$ reversed the effects of CCh (right panels).

to the recording site. The resting membrane potential also depolarized by several millivolts (Dodd et al., 1981). When $1 \mu \mathrm{M}$ atropine, a muscarinic antagonist, was added to this solution, the response was restored to the control conditions with only a few fully propagating spikes. Similar results were obtained in four other cells.

These results clearly show that activation of muscarinic receptors can enhance the propagation of later spikes in a train into the distal dendrites. However, the variety of targets for acetylcholine in the hippocampus makes these experiments difficult to interpret. To avoid complications because of activation of presynaptic receptors (Hounsgaard, 1978) and effects on postsynaptic glutamate receptors (Markram and Segal, 1990), we repeated these experiments by using stimuli in the alveus to activate antidromically the backpropagating spikes in the pyramidal neurons. This stimulation method also allowed us to control the frequency of spike generation. To avoid complications from activation of fast synaptic potentials either directly or through recurrent collaterals, we added $50 \mu \mathrm{m}$ DL-APV, $10 \mu \mathrm{M}$ CNQX, and $10 \mu \mathrm{M}$ BMI to the bath in all subsequent experiments. Figure 2, top row, shows that $\mathrm{CCh}$ had a similar effect on spike backpropagation when the action potentials were evoked antidromically.

Figures 1 and 2 show that $\mathrm{CCh}$ consistently depolarized the pyramidal neurons. One possible explanation for the $\mathrm{CCh}$ effect is that this depolarization itself made it easier for the later spikes in the train to propagate into the dendrites. However, the experiments shown in the bottom row of Figure 2 rule out this mechanism. Current injection of $+0.1 \mathrm{nA}$ depolarized the membrane to the same extent as $1 \mu \mathrm{M}$ CCh but did not enhance spike propagation. Similarly, injection of $-0.07 \mathrm{nA}$ to restore the resting potential to its initial level did not prevent the effect of CCh. Moreover, depolarizing current injection in the presence of $\mathrm{CCh}$ and atropine did not affect propagation. Therefore, although $\mathrm{CCh}$ depolarizes pyramidal cells and can increase the frequency of evoked action potentials (Cole and
Nicoll, 1984), this effect is not responsible for the enhanced dendritic propagation.

\section{Modulation of dendritic $\left[\mathrm{Ca}^{2+}\right]_{i}$ changes}

Backpropagating $\mathrm{Na}^{+}$spikes cause $\left[\mathrm{Ca}^{2+}\right]_{\mathrm{i}}$ changes in the dendrites of CA1 pyramidal neurons. In the distal dendrites these $\left[\mathrm{Ca}^{2+}\right]_{\mathrm{i}}$ increases are dominated by contributions from the first few spikes that propagate to that distance with the largest amplitude (Jaffe et al., 1992; Miyakawa et al., 1992; Callaway and Ross, 1995; Spruston et al., 1995a). Because muscarinic activation increases the amplitude of later spikes in a train, we expected that there might be an associated increase in the $\left[\mathrm{Ca}^{2+}\right]_{\mathrm{i}}$ change under these conditions. In fact, an increase by $\mathrm{CCh}$ of the stimulusevoked $\left[\mathrm{Ca}^{2+}\right]_{\mathrm{i}}$ increase in the dendrites has been described (Muller and Connor, 1991), but the mechanism was not determined. To check this prediction, we made patch recordings in the dendrites with electrodes containing $\mathrm{Ca}^{2+}$ indicators (see Materials and Methods). Figure 3 presents results from a typical experiment. The image shows the electrode and the dendrites filled with Calcium Green-1. The recording location was $\sim 250$ $\mu \mathrm{m}$ from the soma. In response to stimulation in the alveus we recorded a train of action potentials with decreasing amplitudes. At the same time we recorded the fluorescence increase from a rectangular region close to the electrode. As previously shown (see above), the increase peaked at the time of the first few larger amplitude action potentials. When $1 \mu \mathrm{M} C \mathrm{Ch}$ was added to the bath, the amplitude of the later spikes increased. The amplitude of the fluorescence change also increased and peaked at the time of the last spike in the train. When $1 \mu \mathrm{M}$ atropine was added to the superfusate, both the spike profile and the fluorescence change returned to close to the control responses. CCh did not cause a significant change in the resting fluorescence of the cell, suggesting that resting $\left[\mathrm{Ca}^{2+}\right]_{i}$ was not affected (Muller and Connor, 1991). However, it is possible that there were localized increases that were missed by our measurements.

In these experiments the recovery times of the transients were slightly longer than the $100-150 \mathrm{msec}$ recorded with minimal levels of indicator (Callaway and Ross, 1995; Helmchen et al., 1996). Therefore, the $\left[\mathrm{Ca}^{2+}\right]_{i}$ transients may have been buffered, reducing their amplitude and slowing their time course. Nevertheless, the fluorescence records qualitatively indicate the increase in amplitude and the change in time course of the $\left[\mathrm{Ca}^{2+}\right]_{i}$ changes in $\mathrm{CCh}$.

CCh-induced increases in $\Delta F / F$ in the dendrites also were measured with bis-fura- 2 and were measured when whole-cell recordings were made in the soma. There was some variability in the responses, particularly in the extent to which the CChinduced fluorescence changes were reversible (possibly because of photodynamic damage). Nevertheless, an increase in amplitude and change in time course always were observed.

\section{Perforated patch recordings}

We were concerned that the modulation of activity-dependent propagation by $\mathrm{CCh}$ might be an artifact resulting from the dialysis of the cytoplasm by the pipette solution. One possibility was that a change in $\left[\mathrm{Mg}^{2+}\right]_{\mathrm{i}}$ affected $\mathrm{Ca}^{2+}$-activated $\mathrm{K}^{+}$conductances (Lancaster et al., 1991). However, Figure $4 A$ shows that the amplitude of individual spikes was not affected by removing $\mathrm{Mg}^{2+}$ from the pipette solution. We also assessed the effect of removing $\mathrm{Mg}^{2+}$ on the frequency-dependent amplitude reduction. We used the ratio of the amplitude of the last spike in a train of 10 action potentials to the amplitude of the first spike as 


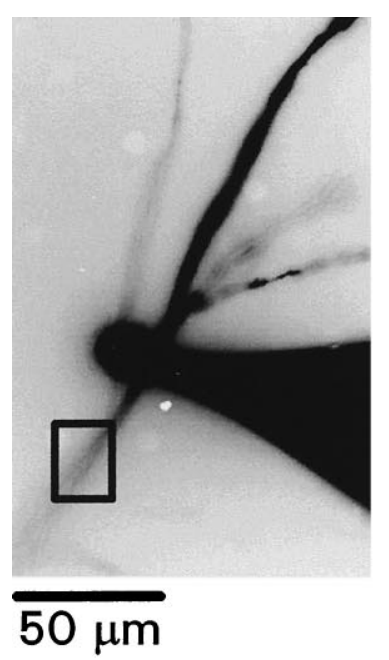

\section{Control}
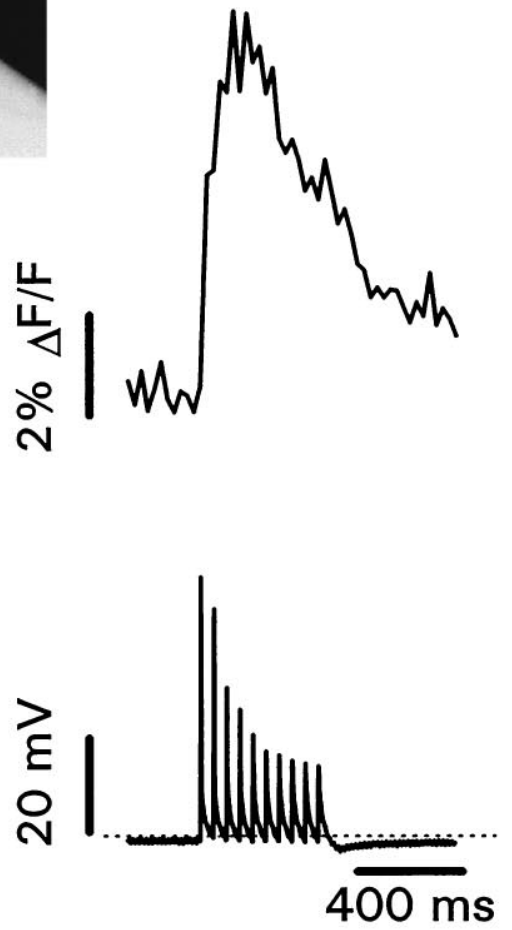

\section{$\operatorname{CCh} 1 \mu \mathrm{M}$}
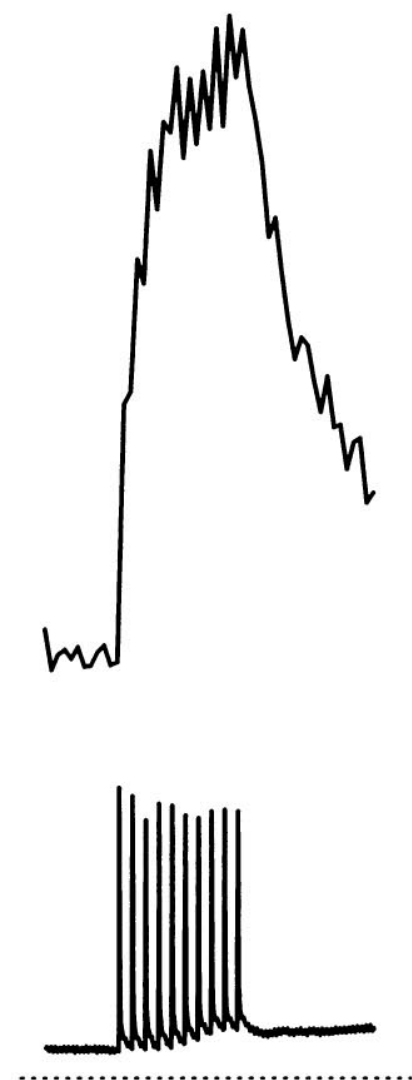

\section{Atropine $1 \mu \mathrm{M}$}
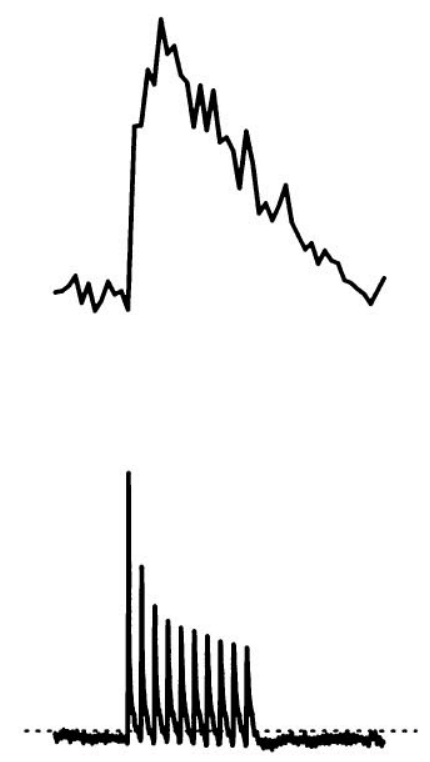

Figure 3. Carbachol increases the amplitude and extends the duration of spike-evoked $\left[\mathrm{Ca}^{2+}\right]_{\mathrm{i}}$ changes in the distal dendrites. Inset shows patch electrode and dendrite filled with $200 \mu \mathrm{M}$ Calcium Green-1. The electrode appears large because it is overexposed. The recording site is $250 \mu \mathrm{m}$ from the soma. Control recordings show the fluorescence change (averaged over the box close to the electrode) and decremental spike heights evoked by a train of stimuli at $50 \mathrm{msec}$ intervals. Note that the fluorescence change peaked after the first few larger amplitude action potentials and then declined, with no change in slope at the end of the train. In $1 \mu \mathrm{M}$ CCh the cell depolarized, and all spike heights were approximately equal. The fluorescence change continued to increase throughout the train, reaching greater peak amplitude. Note that the step for the first action potential was approximately the same as the step under control conditions. The addition of atropine $(1 \mu \mathrm{M})$ restored the potentials and fluorescence changes to control levels.

a measure of this modulation. Figure $4 B$ shows that eliminating internal $\mathrm{Mg}^{2+}$ had no consistent effect on this ratio when the spikes were activated at $50 \mathrm{msec}$ intervals.

A more general control for the consequences of changing the intracellular solution is to make perforated patch recordings (Horn and Marty, 1988; Spruston and Johnston, 1992). When nystatin is used as the ionophore, cations and $\mathrm{Cl}^{-}$are exchanged through the membrane, but no other cytoplasmic constituents are washed out. Using $200 \mu \mathrm{g} / \mathrm{ml}$ nystatin in the pipette solution (see Materials and Methods), we faithfully recorded action potentials from the dendrites at all distances; the access resistance was $<50$ $\mathrm{M} \Omega$ (Fig. 4A). Similarly, there was no systematic change in the frequency-dependent propagation at $20 \mathrm{~Hz}$, although there was considerable scatter in the data (Fig. 4B). When $1 \mu \mathrm{M}$ CCh was added to the bathing solution, this modulation was eliminated at all tested spike intervals (Fig. 5). Similar results were obtained in seven other cells. Therefore, we conclude that whole-cell recording with our standard pipette solution did not introduce artifacts in the $\mathrm{CCh}$ experiments.

\section{Dependence on distance and frequency}

Qualitatively, these results show that $\mathrm{CCh}$ changes the frequencydependent backpropagation of action potentials into the dendrites. To assess these effects quantitatively, we made recordings at different distances from the soma and measured the effect of $\mathrm{CCh}$ on the amplitude of the first and last spike in a train. As shown previously (Turner et al., 1991; Spruston et al., 1995a), the amplitude of the first spike shows smooth decrements from $\sim 100$ $\mathrm{mV}$ in the soma to $\sim 40 \mathrm{mV}$ at $350 \mu \mathrm{m}$ (Fig. 6A, left). The amplitude in the distal dendrites is $\sim 20 \mathrm{mV}$ less than that measured by Spruston et al. (1995a). This difference occurred because our experiments were made at $30-32^{\circ} \mathrm{C}$ and theirs were made at room temperature $\left(22-24^{\circ} \mathrm{C}\right)$, which we could demonstrate directly by turning off the heat on the experimental chamber (data not shown). This panel also shows that at all distances CCh had no significant effect on the amplitude of the first spike.

Figure $6 A$, right panel, shows that in the middle dendrites (150-275 $\mu \mathrm{m}$ from the soma) CCh increased the amplitude of the 

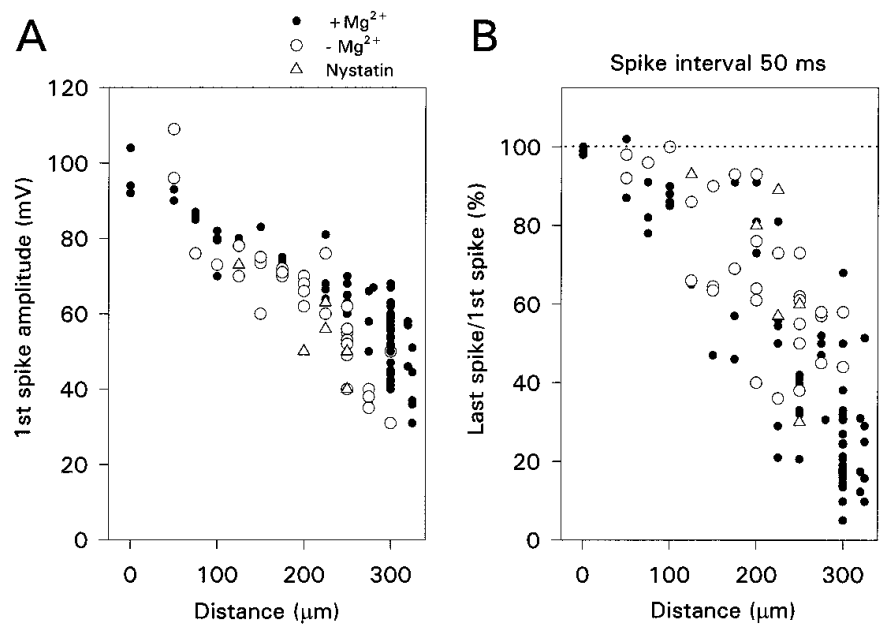

Figure 4. The pattern of spike backpropagation is not affected by wholecell recording conditions. $A$, Amplitude of the first spike in a train as a function of distance of recording electrode from the soma. Each point is a different cell. There was no variation when the electrode contained $4 \mathrm{~mm}$ $\mathrm{Mg}^{2+}(\bigcirc)$, had 0 added $\mathrm{Mg}^{2+}(\bigcirc)$, or if perforated patch recordings were made with electrodes containing nystatin $(\Delta) . B$, Ratio of the amplitude of the 10 th spike in a train to the amplitude of the first spike as a function of the position of the recording electrode. The spike interval was $50 \mathrm{msec}$. The ratio got smaller, indicating greater amplitude reduction, at more distal locations. There was no systematic variation among the different recording conditions.

last spike in the train, often to more than twice the original height. However, in the distal dendrites $(>300 \mu \mathrm{m}$ from the soma) the effect was much smaller. Figure $6 B$ shows these data plotted in a different way; the ratio of the amplitudes of the last and first spikes is shown as a function of the distance from the soma. In control conditions ( filled circles) the ratio decreased with increasing distance from the soma (Spruston et al., 1995a). However, in $\mathrm{CCh}$ the ratio was above $80 \%$ up to $300 \mu \mathrm{m}$ from the soma. A lower ratio beyond this distance was observed in every cell. Figure $6 C$, which compares the amplitudes in $\mathrm{CCh}$ and in control conditions, emphasizes that the effect was on the last spike and not the first. Most of the points far above the dotted diagonal line were from the middle dendritic region.

The amount of activity-dependent amplitude reduction varies as a function of the frequency of stimulation (Callaway and Ross, 1995). This result is shown systematically in Figure $7 B$, which summarizes the results from 55 pyramidal neurons. Maximum peak amplitude reduction was measured when the action potentials were evoked at 50-100 msec intervals and increased with distance from the soma. In many cells some modulation was detectable even with 1-2 sec spike intervals, especially when measured in the distal dendrites (275-300 $\mu \mathrm{m}$ from the soma). The apparently weak modulation at short (10-20 msec) spike intervals may be related more to the way we measured spike amplitudes than to a reduction in the modulatory effect in this frequency range. We define spike amplitude as the difference between the peak potential and the resting potential. In many cells, when the spikes were activated at short intervals, a depolarizing afterpotential developed, increasing the peak potential of later spikes in the train (Fig. 7A). If the spike amplitudes are measured from the point of inflection on the rising phase, there is more modulation at shorter time intervals than the graphs in Figure $7 B$ indicate.

The effect of $\mathrm{CCh}$ on frequency-dependent modulation was measured in a subset of these cells. Figure $7 C$ summarizes these data. At all distances up to $300 \mu \mathrm{m}$ from the soma $\mathrm{CCh}$ reduced or eliminated the amplitude reduction during a train.

\section{Measurements in very distal dendrites}

The apparent conclusion from these data is that $\mathrm{CCh}$ converts action potentials that fail to propagate to the distal dendrites into action potentials that reach the tips of the dendrites. However, recordings from the most distal dendrites suggest that the conversion may not be complete. Figure $8 A$ shows data from a pyramidal neuron recorded $350 \mu \mathrm{m}$ from the soma in whole-cell mode. In normal saline only the first action potential in a train fully propagated to the recording site when the interval was 50 msec between stimuli. Consistent with the data of Figure 6, the peak amplitude of this action potential was $\sim 40 \mathrm{mV}$. When the interval was shortened to $10 \mathrm{msec}$, the afterdepolarizations summated until a wider action potential was generated. Generation of these wider spikes was a consistent observation at this distance when strong stimuli were given. They were probably $\mathrm{Ca}^{2+}$ dependent action potentials, because they were associated with large transient increases in $\left[\mathrm{Ca}^{2+}\right]_{\mathrm{i}}$ (data not shown). When $\mathrm{CCh}$ was applied at a concentration of 10 or $50 \mu \mathrm{M}$, there was no clear effect on the activity-dependent amplitude reduction (Fig. $8 B$ ). Figure $8 C$ shows that the same result was obtained at all spike intervals tested. We can be confident that $\mathrm{CCh}$ was reaching this cell, because the resting potential depolarized when this agent was applied (Fig. 8B). A similar failure of $\mathrm{CCh}$ to reduce the spike amplitude modulation in the very distal dendrites was observed in seven other cells recorded in whole-cell mode. In two of these cells the amplitude of the second and third spikes was increased, but later spikes were unaffected. The enhancement of the earlier spikes may have been a consequence of the tonic depolarization in CCh (Tsubokawa and Ross, 1996a). We attempted to confirm this result by perforated patch and cellattached techniques, but we were unable to make satisfactory recordings $>300 \mu \mathrm{m}$ from the soma.

\section{Receptor subtypes}

Classification of the muscarinic receptor subtypes that are involved may provide a clue to the mechanisms responsible for the frequency-dependent spike amplitude modulation. We tested the effects of pirenzepine and gallamine, putative $\mathrm{M}_{1}$ and $\mathrm{M}_{2}$ receptor antagonists (Hammer and Giachetti, 1984), which have been used previously in this kind of experiment (Dutar and Nicoll, 1988). In the experiment shown in Figure 9, the control recording in the dendrites demonstrated the usual activity-dependent amplitude reduction. When $5 \mu \mathrm{M} \mathrm{CCh}$ and $20 \mu \mathrm{M}$ gallamine were added to the perfusate, the modulation was reduced, suggesting that gallamine did not antagonize the effects of CCh completely, but the gallamine clearly had some effect because washing it out (while leaving in the $\mathrm{CCh}$ ) reduced the modulation further $(n=$ 4). This effect was reversible on reperfusion with gallamine (fourth panel). Finally, removal of gallamine and the addition of $0.3 \mu \mathrm{M}$ pirenzepine completely, blocked the demodulatory effect of CCh. In other experiments, when pirenzepine was added with $\mathrm{CCh}$ at the beginning of the experiment, there also was no reduction in the amplitude modulation $(n=6)$. From these results we conclude that $0.3 \mu \mathrm{M}$ pirenzepine was fully effective in antagonizing the effect of $\mathrm{CCh}$, whereas gallamine was partially effective. These results are consistent with the high levels of $\mathbf{M}_{1}$ and $\mathrm{M}_{3}$ mRNA expression and low levels of $\mathrm{M}_{2}$ and $\mathrm{M}_{4}$ mRNA expression in rat CA1 pyramidal neurons (Buckley et al., 1988). 
Control
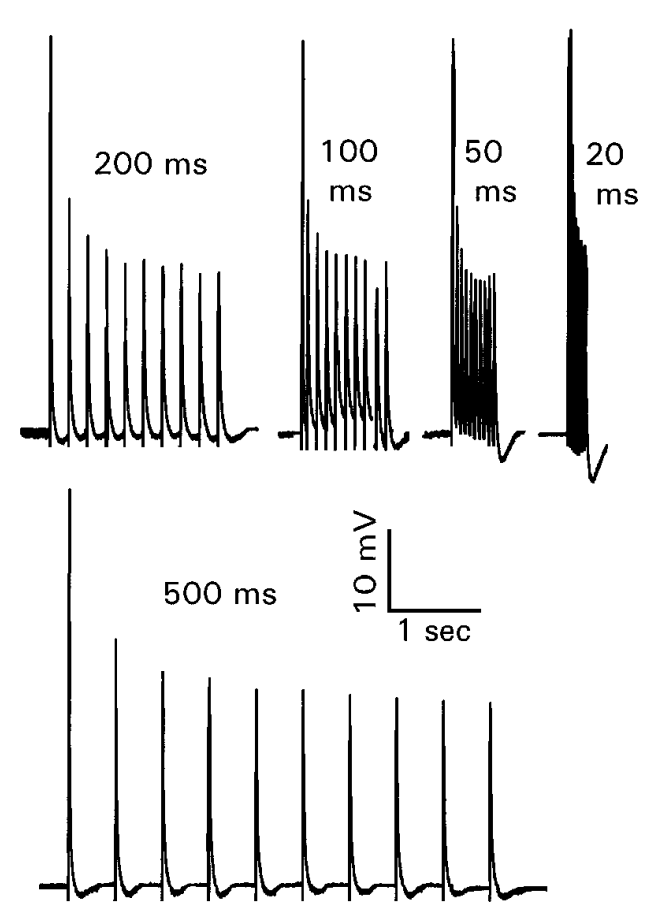

CCh $1 \mu \mathrm{M}$
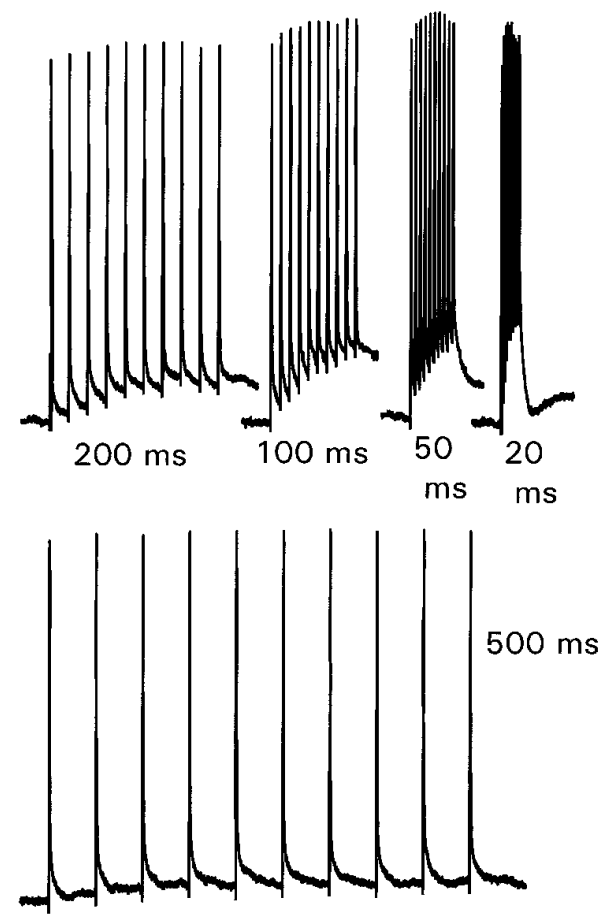

Figure 5. Carbachol enhances spike backpropagation at all spike intervals when perforated patch recording is used. The recording electrode was $250 \mu \mathrm{m}$ from the soma. Control conditions (left) showed clear modulation even at 500 msec intervals. In CCh (right) all spikes had approximately the same amplitude.
Dutar and Nicoll (1988) found that gallamine was $75 \%$ effective in suppressing the M-current. The weak suppression by gallamine of the effect of CCh on spike amplitudes suggests that blockade of the M-current plays only a small role in the amplitude modulation. The complete suppression of the $\mathrm{CCh}$ effect by pirenzepine suggests that $M_{1}$ receptors are important in transducing this muscarinic response. However, Dutar and Nicoll (1988) found that pirenzepine blocked all of the different muscarinic responses in CA1 pyramidal neurons, making it difficult to separate their relative importance. We also note that gallamine and pirenzepine are not completely selective between $\mathrm{M}_{1}$ and $\mathrm{M}_{2}$ receptors, nor is their antagonism to $\mathrm{CCh}$ purely competitive (Hammer and Giachetti, 1984).

\section{Calcium dependence}

One important effect of acetylcholine is the suppression of the slow $\mathrm{Ca}^{2+}$-activated $\mathrm{K}^{+}$conductance that is the primary cause of spike accommodation during a sustained depolarizing stimulus (Bernardo and Prince, 1982; Cole and Nicoll, 1984). Because $\mathrm{Ca}^{2+}$ enters the dendrites after action potentials (Jaffe et al., 1992; Regehr and Tank, 1992), blockade of this conductance might explain the frequency dependence of spike backpropagation. To test this possibility, we made dendritic patch recordings with pipettes containing $10 \mathrm{~mm}$ BAPTA and 0 added $\mathrm{Ca}^{2+}$. Figure 10 (Control) shows that BAPTA did not prevent the amplitude reduction $(n=4)$. A similar result follows from the data of Spruston et al. (1995a) because many of their recordings were made with pipettes containing $10 \mathrm{~mm}$ EGTA. Therefore, a $\mathrm{Ca}^{2+}$-activated $\mathrm{K}^{+}$conductance is unlikely to contribute to this effect. However, BAPTA did suppress the effect of $\mathrm{CCh}$, even when $\mathrm{CCh}$ was used at a concentration of $10 \mu \mathrm{M}$. This result was true for all spike intervals tested (Fig. 10C). The figure also shows that $\mathrm{CCh}$ did not cause a tonic depolarization in the BAPTAfilled cells (compare with Fig. 2), consistent with previous obser- vations (Fraser and MacVicar, 1996). Similar results were obtained when the pipette contained $10 \mathrm{~mm}$ EGTA and 0 added $\mathrm{Ca}^{2+}(n=4)$ or a mixture of $5 \mathrm{~mm}$ EGTA and $0.5 \mathrm{~mm} \mathrm{CaCl}{ }_{2}$. The latter solution was selected to suppress $\left[\mathrm{Ca}^{2+}\right]_{\mathrm{i}}$ transients while maintaining resting $\left[\mathrm{Ca}^{2+}\right]_{i}$ close to normal values. We also note that the buffering effect of $200 \mu \mathrm{M} \mathrm{Ca}{ }^{2+}$ indicator (Fig. 3) was not sufficient to block the effect of $\mathrm{CCh}$.

\section{Effects of other pharmacological agents}

The experiments described so far have concentrated on the muscarinic demodulation of spike propagation induced by $\mathrm{CCh}$. This compound had the clearest effect on the activity-dependent propagation normally observed in CA1 pyramidal neurons. However, it is possible that other conductances, unaffected by muscarinic agonists, could play a role in the activity-dependent spike amplitude reduction. We examined several possible candidates.

We tested compounds that are known to block fast-activating $\mathrm{K}^{+}$conductances in hippocampal pyramidal neurons (Storm, 1993). Apamin (1 $\mu \mathrm{M}, n=3)$, charybdotoxin (100 nM, $n=3)$, 4-aminopyridine (100 $\mu \mathrm{M}, n=3)$, and tetraethylammonium (5 $\mathrm{mm}, n=6$ ) had small effects on the action potential shape in dendritic recordings (Andreasen and Lambert, 1995). However, there was no significant change in the frequency-dependent amplitude reduction (data not shown). These results seem to rule out contributions from the delayed rectifier and the fast $\mathrm{Ca}^{2+}$ activated $\mathrm{K}^{+}$conductance $\left(I_{\mathrm{C}}\right)$. External $\mathrm{CsCl}(0.5-5 \mathrm{~mm})$, which blocks the Q-current (Halliwell and Adams, 1982; Spruston and Johnston, 1992), had variable effects. Usually the first few spikes in a train were increased in amplitude to match the first spike, but the later spikes were affected weakly (data not shown; $n=12$ ). $\mathrm{CsCl}$ consistently hyperpolarized the cell. In the middle dendrites, hyperpolarization by itself often increased the amplitude of action potentials (Fig. 8; Tsubokawa and Ross, 1996a), so it is 

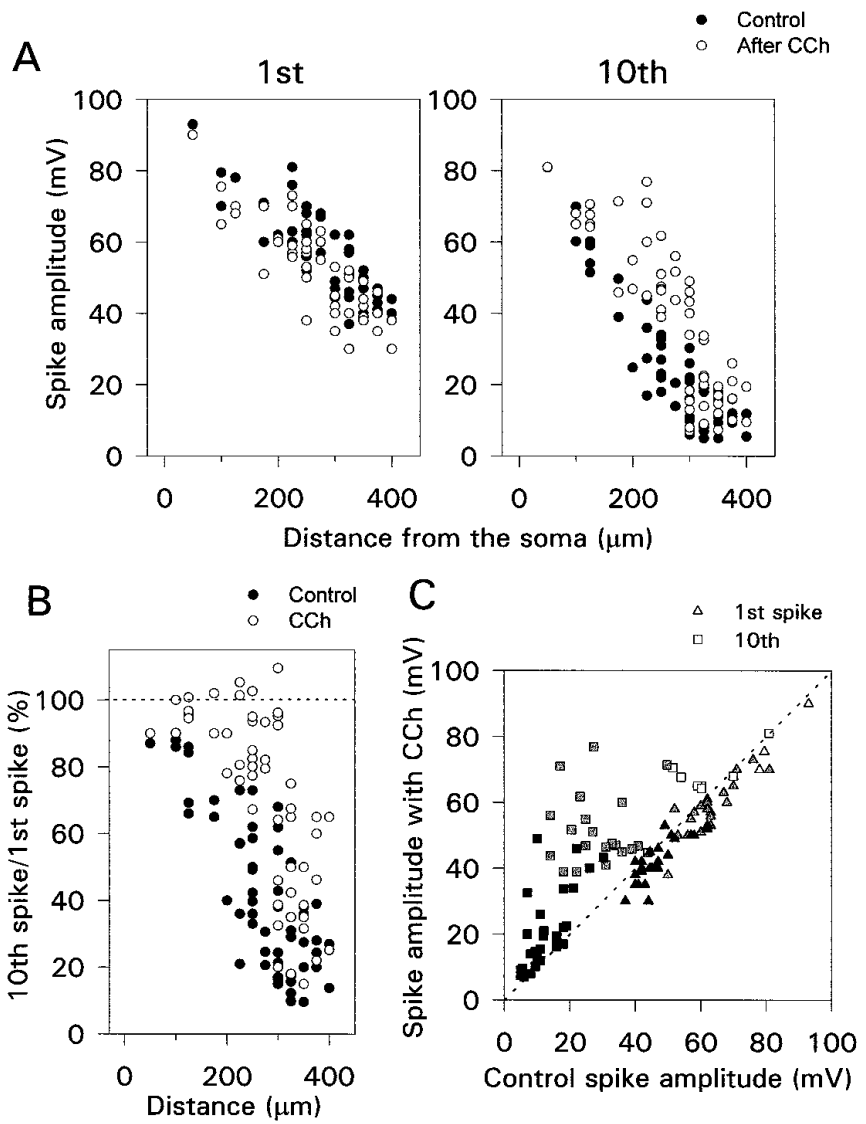

Figure 6. Effect of CCh on the amplitude of the first and last spikes in a train of 10 action potentials evoked at $50 \mathrm{msec}$ intervals. A, Amplitude of first and last spikes as a function of distance from the soma. $\mathrm{CCh}$ had little effect on the first spike but increased the amplitude of the last spike, especially at distances $150-300 \mu \mathrm{m}$ from the soma. Data from each cell are plotted twice-once in control conditions $(\bullet)$ and once in $\mathrm{CCh}(\bigcirc)$. $B$, Same data plotted to show the ratio of the amplitudes versus distance. The ratio was enhanced in $\mathrm{CCh}$ in the more distal parts of the cell. The enhancement near $400 \mu \mathrm{m}$ was attributable primarily to a reduction in the first spike amplitude (usually not reversible). $C$, Same data plotted to show the amplitudes in CCh versus the amplitudes in normal saline. White (proximal dendrites, 0-125 $\mu \mathrm{m}$ ); gray (middle, 150-275 $\mu \mathrm{m}$ ); black (distal, $\geq 300 \mu \mathrm{m})$. Each point is from a single cell.

possible that this weak effect was mediated partially by the hyperpolarization alone.

Norepinephrine (NE; $20 \mu \mathrm{M})$, which blocks the slow $\mathrm{Ca}^{2+}$ activated $\mathrm{K}^{+}$conductance and reduces spike accommodation (Madison and Nicoll, 1982), had no effect when the spike interval was $50 \mathrm{msec}(n=9)$, whereas CCh had dramatic effects. However, at longer intervals $(0.5-2 \mathrm{sec})$ the modulation was reduced and was reversible ( $n=2$; data not shown). This effect was not examined further in this series of experiments.

\section{DISCUSSION}

Pyramidal neurons in the CA1 region of the rat hippocampus typically fire at a rate of $0.5-20$ action potentials/sec during normal behavior (Muller et al., 1987). In this frequency range the amplitude of backpropagating action potentials in the distal dendrites will be less than the maximum amplitude (Fig. 7). Therefore, almost all action potentials will be sensitive to the muscarinic effect described in these experiments. We found that $1 \mu \mathrm{M}$ $\mathrm{CCh}$ typically blocked activity-dependent reduction in spike am-
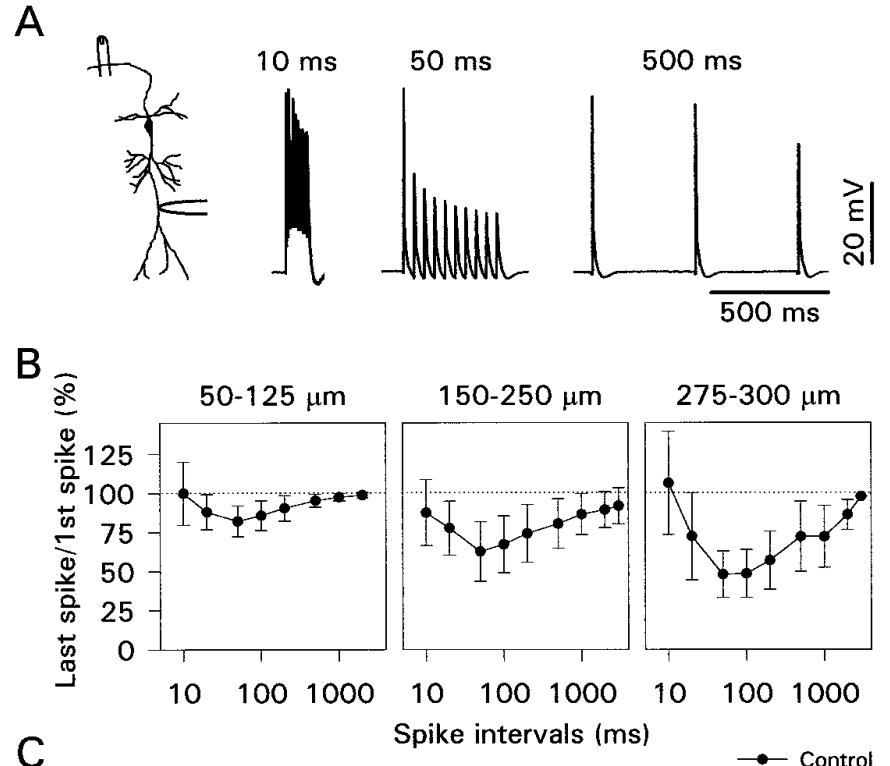

C

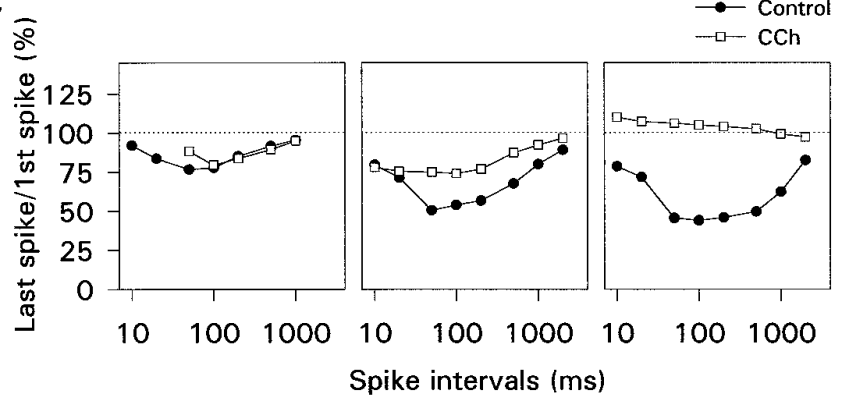

Figure 7. Carbachol reverses amplitude reduction at all spike intervals. $A$, Examples of activity-dependent amplitude reduction at different spike intervals recorded $275 \mu \mathrm{m}$ from the soma. Note that the summating depolarizing afterpotentials enhanced the amplitude of later spikes at 10 msec intervals. $B$, Activity-dependent amplitude reduction as a function of spike interval and distance for 55 pyramidal neurons. Modulation increased with distance from the soma and was most pronounced at 50-100 msec intervals. $C$, Effect of CCh on amplitude modulation for those cells that were analyzed completely. Two cells at $50-125 \mu \mathrm{m}$, six cells at $150-250 \mu \mathrm{m}$, and four cells at $275-300 \mu \mathrm{m}$ were included.

plitude, with $0.75 \mu \mathrm{M}$ producing detectable effects on spike height (data not shown). This level of sensitivity is comparable to the effects of $\mathrm{CCh}$ on the M-current and the slow $\mathrm{Ca}^{2+}$-activated $\mathrm{K}^{+}$ conductance (Madison et al., 1987), which are responsible for cholinergic reduction of spike accommodation. Consequently, modulation of dendritic spike propagation should occur whenever spike accommodation is observed. Interestingly, recent experiments (Tang and Sejnowski, 1996) suggest that accommodation may be minimal when physiologically realistic fluctuating inputs (instead of depolarizing pulses) are used to evoke action potentials. Therefore, enhancement of spike backpropagation may be a more significant effect of cholinergic activation in these cells.

\section{Mechanism of activity-dependent backpropagation}

Jaffe et al. (1992) suggested that a $\mathrm{Ca}^{2+}$-activated $\mathrm{K}^{+}$conductance could be responsible for the variable propagation in hippocampal cells. Our experiments showing no change in the propagation pattern with intracellular BAPTA or EGTA (Fig. 10) rule out this explanation. Migliore (1996) suggested that either slow inactivation of $\mathrm{Na}^{+}$channels or a slow voltage-activated shunting conductance in the dendrites could explain activity-dependent 

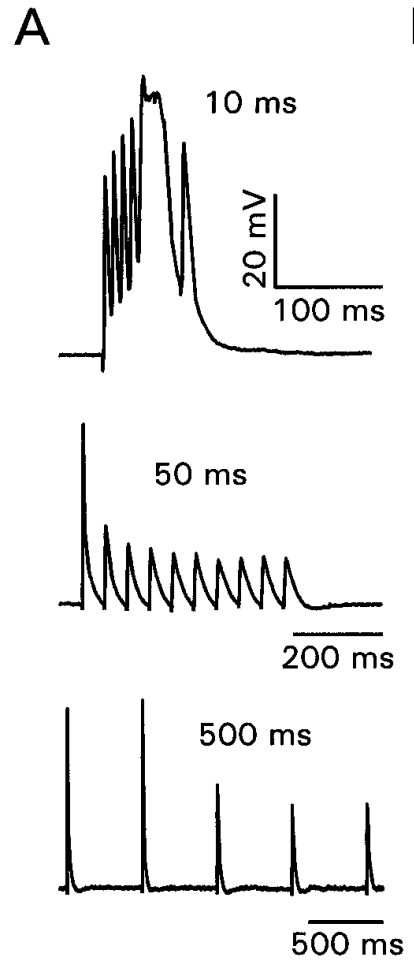

B

Control

$\mathrm{CCh}$

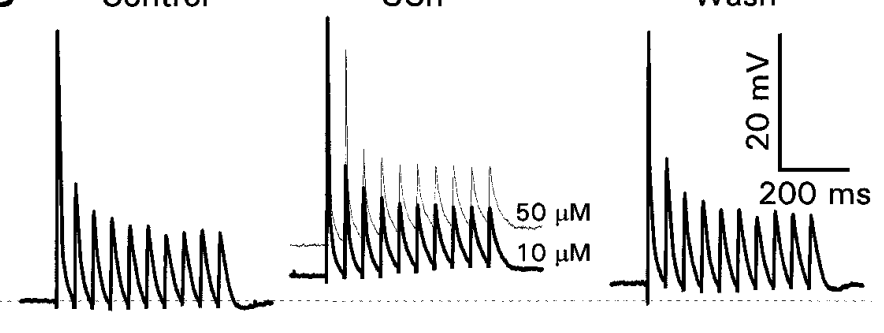

C

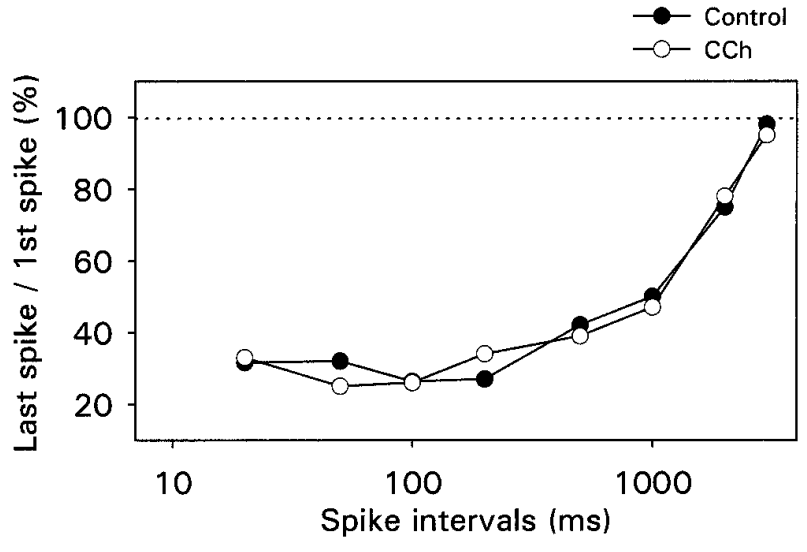

Figure 8. Carbachol does not enhance spike amplitudes in the very distal dendrites. $A$, Spikes evoked at different intervals recorded $350 \mu \mathrm{m}$ from the soma. Note that at $10 \mathrm{msec}$ intervals the summating afterpotentials initiated a wide, larger amplitude action potential. $B$, $\mathrm{CCh}$ at 10 or $50 \mu \mathrm{M}$ depolarized the cell but did not increase the amplitude of the later spikes in the train. $C$, Data from recordings at many intervals. In all tested intervals CCh had no clear effect on spike height.
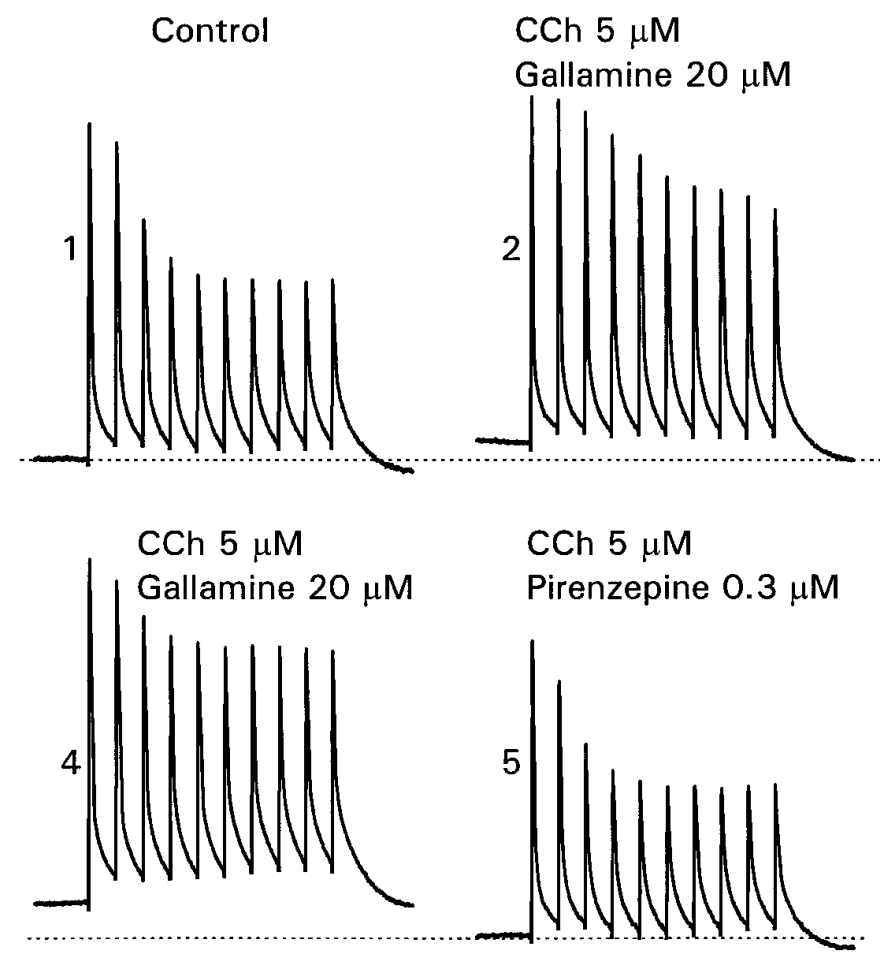

propagation in his computational model. There is some experimental evidence supporting the role of slow $\mathrm{Na}^{+}$channel inactivation (Colbert and Johnston, 1996b), but it is not known if this slow inactivation is the only mechanism involved. If slow $\mathrm{Na}^{+}$ channel inactivation is responsible, then removal of this inactivation is not likely to be the mechanism for the effect of $\mathrm{CCh}$ because $\mathrm{CCh}$ reduces peak $\mathrm{Na}^{+}$current and slows inactivation in channels from CA1 pyramidal neurons (Cantrell et al., 1996). In principle, the M-current or the nonspecific cation conductance
Figure 9. Effects of selective muscarinic antagonists on activity-dependent amplitude reduction. 1, Recording $225 \mu \mathrm{m}$ from soma in control conditions. 2, CCh $(5 \mu \mathrm{M})$ and gallamine $(20 \mu \mathrm{M})$ together slightly depolarized the cell and partially reduced the amplitude modulation. 3, Removing gallamine (leaving $\mathrm{CCh}$ ) further depolarized the membrane and eliminated the amplitude modulation. 4, Adding back gallamine restored the initial response. 5, Removing gallamine and adding $0.3 \mu \mathrm{M}$ pirenzepine $(5 \mu \mathrm{M} \mathrm{CCh}$ still included) restored the response to control potentials. described by Benson et al. (1988) and others could qualify as the shunting conductance.

The blockade of the CCh effect by BAPTA does not seem to be consistent with a role for the M-current because Madison et al. (1987) found that the CCh-mediated suppression of this current persisted in $\mathrm{Cd}^{2+}$-containing saline. More directly, Dutar and Nicoll (1988) found that buffering $\left[\mathrm{Ca}^{2+}\right]_{\mathrm{i}}$ with BAPTA (at a concentration sufficient to block the slow AHP) had no effect on the suppression of the M-current by CCh. However, other exper- 


\section{$10 \mathrm{mM}$ BAPTA in pipette}

Figure 10. Intracellular BAPTA has no effect on activity-dependent amplitude reduction but blocks the effect of carbachol. With $10 \mathrm{~mm}$ BAPTA in the pipette $(250 \mu \mathrm{m}$ from the soma) the spike heights had the typical activity dependence, with no effect of $\mathrm{CCh}$ at any spike interval.

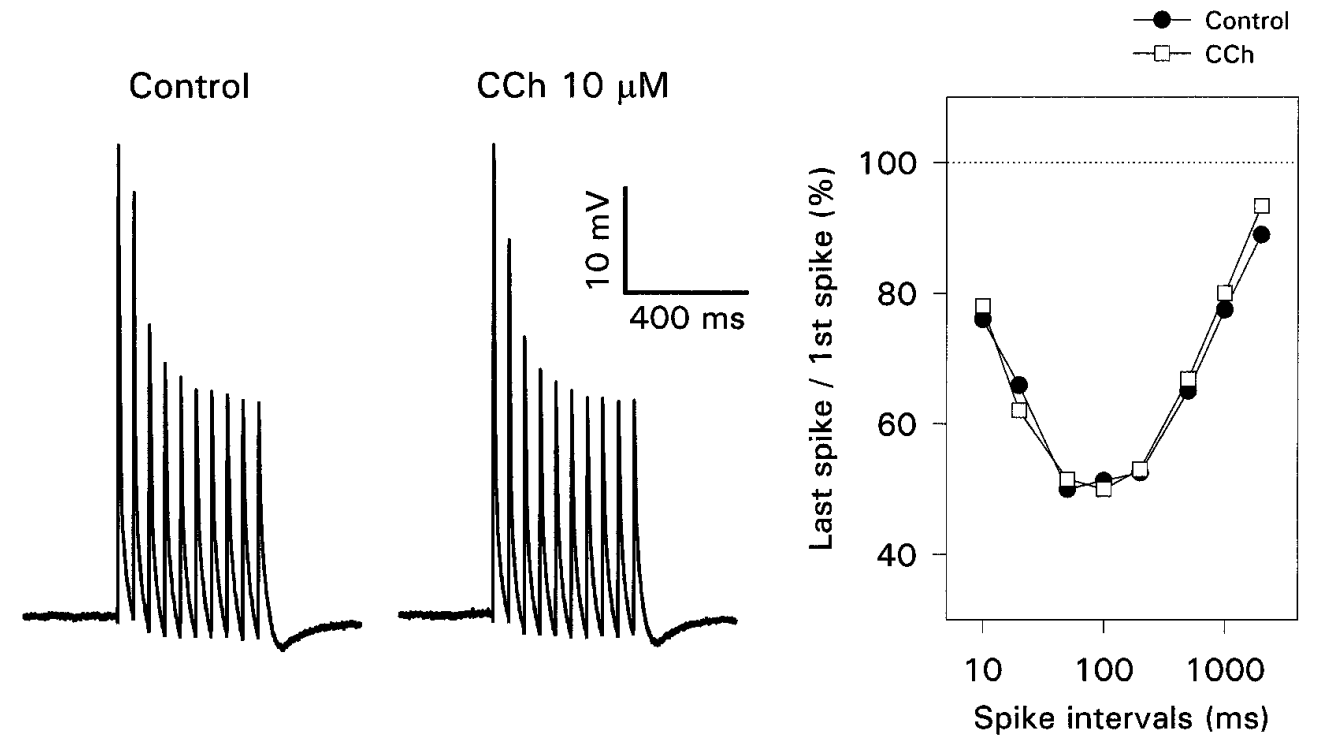

iments suggest that the suppression of the M-current (at least in sympathetic ganglia) is mediated by a rise in $\left[\mathrm{Ca}^{2+}\right]_{i}$ released from internal stores (Kirkwood et al., 1991). Although we did not measure a rise in $\left[\mathrm{Ca}^{2+}\right]_{\mathrm{i}}$ via this pathway, it is possible that our apparatus was not sufficiently sensitive. If $\mathrm{a} \mathrm{Ca}^{2+}$-mediated suppression of a $\mathrm{K}^{+}$conductance is involved in the $\mathrm{CCh}$ response, then the specific target may be the recently discovered ether- $\grave{a}$ go-go channel (Warmke et al., 1991; Stansfeld et al., 1996).

$\mathrm{CCh}$ reverses the activity-dependent spike amplitude reduction. However, it is not clear that it does so by blocking the conductance responsible for the reduction. Indeed, the inability of $\mathrm{CCh}$ to reverse the amplitude reduction in very distal dendrites (Fig. 8) suggests that different mechanisms are at work. Therefore, even if suppression of the M-current does not contribute to the effect of $\mathrm{CCh}$ on spike propagation, it still could have a role in the activity-dependent amplitude reduction observed under normal conditions.

\section{Functional significance}

Carbachol and other cholinergic agonists have many effects in the hippocampus, including the induction of bursts and oscillations (Bianchi and Wong, 1994) and modulation of synaptic plasticity (Blitzer et al., 1990; Huerta and Lisman, 1993). These effects may be mediated via changes in membrane conductances (Nicoll, 1985), induction of protein synthesis (Feig and Lipton, 1993), or other cellular mechanisms. It is not certain whether the enhancement of dendritic spike propagation relates to these more global effects.

There is evidence that backpropagating spikes are important for the induction of some forms of Hebbian synaptic plasticity. Recent experiments in the hippocampus (Magee and Johnston, 1997) and cortex (Markram et al., 1997) have shown that blocking these spikes can prevent LTP or LTD in some protocols. One possibility is that the spikes act via the $\left[\mathrm{Ca}^{2+}\right]_{\mathrm{i}}$ increases they evoke. In this case the increased amplitude, longer duration, and increased spatial extent of the $\left[\mathrm{Ca}^{2+}\right]_{\mathrm{i}}$ increases in $\mathrm{CCh}$ (Fig. 3) presumably would enhance these effects. A second possibility is that the voltage change of the backpropagating spikes directly affects some cellular function. For example, the conductance of NMDA receptor channels has an apparent voltage dependence because of the blocking effect of $\mathrm{Mg}^{2+}$. In the dendrites the action potential usually is initiated on the falling phase of the synaptic potential (Fig. 1) when only NMDA receptors are likely to be open (Spruston et al., 1995b). At this time they may be particularly sensitive to the changes in spike amplitude induced by $\mathrm{CCh}$.

Backpropagating action potentials also can affect dendritic physiology in ways that are more straightforward. To illustrate, the $\left[\mathrm{Ca}^{2+}\right]_{\mathrm{i}}$ increases caused by the spikes will turn on $\mathrm{Ca}^{2+}$ activated $\mathrm{K}^{+}$conductances in the dendritic membrane. The resulting hyperpolarization will oppose the depolarization of the summating EPSPs, preventing the activation of voltagedependent channels in the dendrites (Magee and Johnston, 1995a), which, in turn, should influence the way the EPSPs contribute to action potential initiation.

\section{REFERENCES}

Andreasen M, Lambert JDC (1995) Regenerative properties of pyramidal cell dendrites in area CA1 of the rat hippocampus. J Physiol (Lond) 483:421-441.

Benson DM, Blitzer RD, Landau EM (1988) An analysis of the depolarization produced in guinea-pig hippocampus by cholinergic receptor stimulation. J Physiol (Lond) 404:479-496.

Bernardo LS, Prince DA (1982) Ionic mechanism of cholinergic excitation in mammalian hippocampal pyramidal cells. Brain Res 249:333-344.

Bianchi R, Wong RKS (1994) Carbachol-induced synchronized rhythmic burst in CA3 neurons of guinea pig hippocampus in vitro. J Neurophysiol 72:131-138.

Blanton MG, LoTurco JJ, Kriegstein AR (1989) Whole-cell recording from neurons in slices of reptilian and mammalian cerebral cortex. J Neurosci Methods 30:203-210.

Blitzer RD, Gil O, Landau EM (1990) Cholinergic stimulation enhances long-term potentiation in the CA1 region of rat hippocampus. Neurosci Lett 119:207-210.

Borst JGG, Helmchen F, Sakmann B (1995) Pre- and postsynaptic whole-cell recordings in the medial nucleus of the trapezoid body of the rat. J Physiol (Lond) 489:825-840.

Buckley NJ, Bonner TI, Brann MR (1988) Localization of a family of muscarinic receptor mRNAs in rat brain. J Neurosci 8:4646-4652.

Callaway JC, Ross WN (1995) Frequency-dependent propagation of sodium action potentials in dendrites of hippocampal CA1 pyramidal neurons. J Neurophysiol 74:1395-1403.

Callaway JC, Lasser-Ross N, Ross WN (1995) IPSPs strongly inhibit climbing fiber-activated $\left[\mathrm{Ca}^{2+}\right]_{\mathrm{i}}$ increases in the dendrites of cerebellar Purkinje neurons. J Neurosci 15:2777-2787.

Cantrell AR, Ma JY, Scheuer T, Catterall WA (1996) Muscarinic mod- 
ulation of sodium current by activation of protein kinase $\mathrm{C}$ in rat hippocampal neurons. Neuron 16:1019-1026.

Colbert CM, Johnston D (1996a) Axonal action potential initiation and $\mathrm{Na}^{+}$channel densities in the soma and axon initial segment of subicular pyramidal neurons. J Neurosci 16:6676-6686.

Colbert CM, Johnston D (1996b) A decrease in $\mathrm{Na}^{+}$current contributes to loss of action potential amplitude in dendritic spike trains. Soc Neurosci Abstr 22:791.

Cole AE, Nicoll RA (1984) Characterization of a slow cholinergic postsynaptic potential recorded in vitro from rat hippocampal pyramidal cells. J Physiol (Lond) 352:173-188.

Dodd J, Dingledine R, Kelly JS (1981) The excitatory action of acetylcholine on hippocampal neurons of the guinea-pig and rat maintained in vitro. Brain Res 207:109-127.

Dutar P, Nicoll RA (1988) Classification of muscarinic responses in hippocampus in terms of receptor subtypes and second messenger systems: electrophysiological studies in vitro. J Neurosci 8:4214-4224.

Feig S, Lipton P (1993) Pairing the cholinergic agonist carbachol with patterned Schaffer collateral stimulation initiates protein synthesis in hippocampal CA1 pyramidal cell dendrites via a muscarinic, NMDAdependent mechanism. J Neurosci 13:1010-1021.

Fraser DD, MacVicar BA (1996) Cholinergic-dependent plateau potential in hippocampal CA1 pyramidal neurons. J Neurosci 16:4113-4128.

Gustafsson B, Wigstrom H, Abraham WC, Huang Y-Y (1987) Longterm potentiation in the hippocampus using depolarizing current pulses as the conditioning stimulus to single volley synaptic potentials. J Neurosci $7: 774-780$.

Halliwell JV, Adams PR (1982) Voltage-clamp analysis of muscarinic excitation in hippocampal neurons. Brain Res 250:71-92.

Hammer R, Giachetti A (1984) Selective muscarinic receptor antagonists. Trends Pharmacol Sci 5:18-20.

Helmchen F, Imoto K, Sakmann B (1996) $\mathrm{Ca}^{2+}$ buffering and action potential-evoked $\mathrm{Ca}^{2+}$ signaling in dendrites of pyramidal neurons. Biophys J 70:1069-1081.

Horn R, Marty A (1988) Muscarinic activation of ionic currents measured with a new whole-cell recording method. J Gen Physiol 92:145-159.

Hounsgaard J (1978) Presynaptic inhibitory action of acetylcholine in area CA1 of the hippocampus. Exp Neurol 62:787-797.

Huerta PT, Lisman JE (1993) Heightened synaptic plasticity of hippocampal CA1 neurons during a cholinergically induced rhythmic state. Nature 394:723-725.

Jaffe DB, Johnston D, Lasser-Ross N, Lisman JE, Miyakawa H, Ross WN (1992) The spread of $\mathrm{Na}^{+}$spikes determines the pattern of dendritic $\mathrm{Ca}^{2+}$ entry into hippocampal neurons. Nature 357:244-246.

Kirkwood A, Simmons MA, Mather RJ, Lisman J (1991) Muscarinic suppression of the M-current is mediated by a rise in internal $\mathrm{Ca}^{2+}$ concentration. Neuron 6:1009-1014.

Krnjevic K (1993) Central cholinergic mechanisms and function. Prog Brain Res 98:285-292.

Kullman DM, Perkel DJ, Manabe T, Nicoll RA (1992) $\mathrm{Ca}^{2+}$ entry via postsynaptic voltage-sensitive $\mathrm{Ca}^{2+}$ channels can transiently potentiate excitatory transmission in the hippocampus. Neuron 9:1177-1183.

Lancaster B, Nicoll RA, Perkel DJ (1991) Calcium activates two types of potassium channels in rat hippocampal neurons in culture. J Neurosci 11:23-30.

Lasser-Ross N, Miyakawa H, Lev-Ram V, Young SR, Ross WN (1991) High time resolution fluorescence imaging with a CCD camera. J Neurosci Methods 36:253-261.

Madison DV, Nicoll RA (1982) Noradrenaline blocks accommodation of pyramidal cell discharge in the hippocampus. Nature 299:636-638.

Madison DV, Lancaster B, Nicoll RA (1987) Voltage-clamp analysis of cholinergic action in the hippocampus. J Neurosci 7:733-741.

Magee JC, Johnston D (1995a) Synaptic activation of voltage-gated channels in the dendrites of hippocampal pyramidal neurons. Science 268:301-304.

Magee JC, Johnston D (1995b) Characterization of single voltage-gated $\mathrm{Na}^{+}$and $\mathrm{Ca}^{2+}$ channels in apical dendrites of rat CA1 pyramidal neurons. J Physiol (Lond) 481:67-90.

Magee JC, Johnston D (1997) A synaptically controlled associative signal for Hebbian plasticity in hippocampal neurons. Science 275:209-213.

Markram H, Segal M (1990) Long-lasting facilitation of excitatory postsynaptic potentials in the rat hippocampus by acetylcholine. J Physiol (Lond) 427:381-393.

Markram H, Lubke J, Frotscher M, Sakmann B (1997) Regulation of synaptic efficacy by coincidence of postsynaptic APs and EPSPs. Science 275:213-215.

Migliore M (1996) Modeling the attenuation and failure of action potentials in the dendrites of hippocampal neurons. Biophys J 71:2394-2403.

Miyakawa H, Ross WN, Jaffe D, Callaway JC, Lasser-Ross N, Lisman JE, Johnston D (1992) Synaptically activated increases in $\mathrm{Ca}^{2+}$ concentration in CA1 pyramidal cells are primarily due to voltage-gated $\mathrm{Ca}^{2+}$ channels. Neuron 9:1163-1173.

Muller RU, Kubie JL, Ranck Jr JB (1987) Spatial firing patterns of hippocampal complex-spike cells in a fixed environment. J Neurosci 7:1935-1950.

Muller W, Connor JA (1991) Cholinergic input uncouples $\mathrm{Ca}^{2+}$ changes from $\mathrm{K}^{+}$conductance activation and amplifies intradendritic $\mathrm{Ca}^{2+}$ changes in hippocampal neurons. Neuron 6:901-905.

Nicoll RA (1985) The septo-hippocampal projection: a model cholinergic pathway. Trends Neurosci 8:533-536.

Regehr WG, Tank DW (1992) Calcium concentration dynamics produced by synaptic activation of CA1 pyramidal cells. J Neurosci 12:4202-4223.

Spruston N, Johnston D (1992) Perforated patch-clamp analysis of the passive membrane properties of three classes of hippocampal neurons. J Neurophysiol 67:508-529.

Spruston N, Schiller Y, Stuart G, Sakmann B (1995a) Activitydependent action potential invasion and calcium influx into hippocampal CA1 dendrites. Science 268:297-300.

Spruston N, Jonas P, Sakmann B (1995b) Dendritic glutamate receptor channels in rat hippocampal CA3 and CA1 pyramidal neurons. J Physiol (Lond) 482:325-352.

Stansfeld CE, Roper J, Ludwig J, Weseloh RM, Marsh SJ, Brown DA, Pongs O (1996) Elevation of intracellular calcium by muscarinic receptor activation induces a block of voltage-activated rat ether-à-go-go channels in a stably transfected cell line. Proc Natl Acad Sci USA 93:9910-9914.

Storm JF (1993) Functional diversity of $\mathrm{K}^{+}$currents in hippocampal pyramidal neurons. Semin Neurosci 5:79-92.

Stuart G, Sakmann B (1994) Active propagation of somatic action potentials into neocortical pyramidal cell dendrites. Nature 367:69-72.

Tang AC, Sejnowski TJ (1996) Preservation of spike timing and increased excitability under cholinergic modulation in neocortical neurons. Soc Neurosci Abstr 22:1254.

Tsubokawa H, Ross WN (1996a) IPSPs modulate spike backpropagation and associated $\left[\mathrm{Ca}^{2+}\right]_{\mathrm{i}}$ changes in the dendrites of hippocampal CA1 pyramidal neurons. J Neurophysiol 76:2896-2906.

Tsubokawa H, Ross WN (1996b) Pharmacological modulation of spike propagation in the apical dendrites of hippocampal pyramidal cells. Soc Neurosci Abstr 22:791.

Turner RW, Meyers DE, Richardson TL, Barker JL (1991) The site for initiation of action potential discharge over the somatodendritic axis of hippocampal CA1 pyramidal cell neurons. J Neurosci 11:2270-2280.

Warmke J, Drysdale R, Ganetzky B (1991) A distinct potassium channel polypeptide encoded by the Drosophila eag locus. Science 252:1560-1562.

Wong RKS, Prince DA, Basbaum AI (1979) Intradendritic recordings from hippocampal neurons. Proc Natl Acad Sci USA 76:986-990. 